SEM/AFM 破面観察による超長寿命疲労機構の考察†

$$
\begin{array}{r}
\text { 村 上 敬 宜* 野 本 哲 志** 植 } \\
\text { 村 上 保 夫** 大 堀 学*** } \\
\text { Analysis of the Mechanism of Superlong Fatigue Failure } \\
\text { by Optical Microscope and SEM/AFM Observations }
\end{array}
$$

by

\author{
Yukitaka Murakami ${ }^{*}$, Tetsushi Nomoto ${ }^{* *}$, Toru UedA ${ }^{* *}$, \\ Yasuo MuRAKAMI ${ }^{* * *}$ and Manabu OHORI ${ }^{* * *}$
}

Since in superlong fatigue failure with $N_{f} \geqq 10^{8}$, the average fatigue crack growth rate is much less than lattice spacing $\left(\sim 0.1 \AA\right.$ or $0.01 \mathrm{~nm}$ or $10^{-11 \sim-12} \mathrm{~m} /$ cycle $)$, we cannot assume that crack growth occurs cycle by cycle in the early stage of fatigue process.

In this paper, possible mechanisms for extremely high cycle fatigue are discussed. A special attention was paid to a newly found particular fatigue fracture morphology in the vicinity of fracture origin(nonmetallic inclusions) of a heat treated alloy steel, SCM435. The particular morphology looks a dark area inside fish-eye mark by optical microscopic observation. Specimens with short fatigue life of $N=\sim 10^{5}$ do not have such dark area in fish-eye mark. SEM and $\mathrm{AFM}$ observations revealed that the dark area has a rough surface quite different from usual fatigue fracture surface in martensite lath structure. The predictions of fatigue limit by the $\sqrt{\text { area }}$ parameter model are $\sim 10 \%$ unconservative for fatigue limit defined for $N=10^{7}$. Thus, the fatigue failure for $N \geqq 10^{8}$ is presumed to be caused by a mechanism which induces breaking or releasing of fatigue crack closure phenomenon in small cracks. The breaking or releasing crack closure mechanism is presumed to be caused by environmental effects such as hydrogen embrittlement coupled with extremely high cycle fatigue. Some indirect evidences to support this hypothesis are shown.

Key words : Superlong fatigue failure, Nonmetallic inclusions, Fish-eye, Hydrogen embrittlement, The $\sqrt{\text { area }}$ parameter model, SEM, AFM

\section{1 緒—言}

低強度鋼では $S-N$ 曲線は明確な折れ曲がりを示すの で，それによって疲労限度を明確に定義することができ る.これに対して高強度鋼の $S-N$ 線図ではばらつきが大 きく，明確な線をひくことが困難である。近年高強度鋼 を繰返し数 $N=10^{8}$ 程度まで疲労試験すると 2 段の折れ 曲がり現象が現われるとする報告がなされ，注目されて いる. ${ }^{1) \sim 4)}$ これは高強度鋼の $S-N$ 線図に打いて $N \cong 10^{6} \sim$ $10^{7}$ の高サイクル領域で一旦水平部が現われた後, 超長 寿命領域に打いて再び下方に折れ曲がる現象である。一 般にこの現象は高応力域で表面起点, 低応力域で内部起 点という破壊起点の違いが原因であるとされているが， 高応力短寿命域でも内部の介在物から破壊が起きること を示すデータも数多く報告されている.1), 5) したがって， 2 段折れ曲がり現象を単なる破壊起点の位置の違いだけ から説明するのは困難である。一方, 高強度鋼は欠陥や， 水素などの環境因子に敏感であると言われている。 また， 超長寿命領域まで度労試験を行うと, 試験片は長期間大 気等の環境中にさらされることになる。したがって高強 度鋼の超長寿命領域におけ方疲労機構を解明するために
は，応力の作用のもとでの環境因子の影響を考慮に入れ る必要があると考えられる。

そこで本研究では, SCM435 浸炭窒化・焼入れ焼もど し材を用いて $N=10^{8}$ を超える超長寿命領域まで引張圧 縮疲労試験を行门，特に破断起点となった介在物近傍に 注目して金属顕微鏡, 走查型電子顕微鏡 (SEM) および 原子間力顕微鏡 $(\mathrm{AFM})$ による疲労破面の観察を行っ た。また，午の観察結果に $\sqrt{\text { area }}$ パラメータモデル ${ }^{5), 6)}$ 等による検討を加え，超長寿命領域における疲労に及ぼ す水素などの環境因子の影響について考察した。

\section{2 供試材および実験方法}

供試材は, クロムモリブデン鋼 SCM435 の浸炭窒化・ 焼入れ焼もどし材である. Table I に供試材の化学成分 を示す．表面処理方法は，浸炭窒化後， $850^{\circ} \mathrm{C}$ 焼入れ， $170^{\circ} \mathrm{C}$ 焼もどし処理である. Fig. 1 に試験片形状を示す. 試験部の表面硬化層を残すために電解研磨等は行わなか った. Fig. 2 に試験部断面のビッカース硬さ $H V$ の分布 例を示す．表面硬化層が残っているために，表面が内部 に比べて硬いことが分かる。また，X線応力測定の結果 試験片表面には，約 $500 \mathrm{MPa}$ 程度の圧縮残留応力が存在

$\dagger \quad$ 原稿受理 平成 10 年 12 月 21 日 Received Dec. 21, 1998

* 正 会 員 九州大学工学部機械工学科 †812-8581 福岡市東区箱崎, Dept. of Mec. Sci. \& Eng., Kyushu Univ., Higashi-ku, Fukuoka, 812-8581

** 九州大学大学院 T812-8581 福岡市東区箱崎, Graduate Sutudent, Kyushu Univ., Higashi-ku, Fukuoka, 812-8581

*** 日本精工(株)基盤技術研究所 T251-8501 藤沢市鵠沼神明, NSK Ltd., Kugenuma Shinmei, Fujisawa, 251-8501 
Table I. Chemical composition.

$(w+x)(p p m)$

\begin{tabular}{|c|c|c|c|c|c|c|c|c|c|}
\hline $\mathrm{C}$ & $\mathrm{Si}$ & $\mathrm{Mn}$ & $\mathrm{P}$ & $\mathrm{S}$ & $\mathrm{Ni}$ & $\mathrm{Gr}$ & $\mathrm{Mo}$ & $\mathrm{Cu}$ & $\mathrm{O}_{2}$ \\
\hline 0.36 & 0.19 & 0.77 & 0.014 & 0.006 & 0.08 & 1.00 & 0.15 & 0.13 & 8 \\
\hline
\end{tabular}

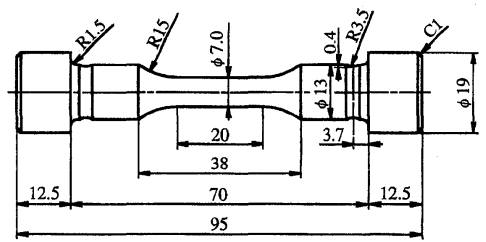

Fig. 1. Tension compression fatigue specimen, $\mathrm{mm}$.

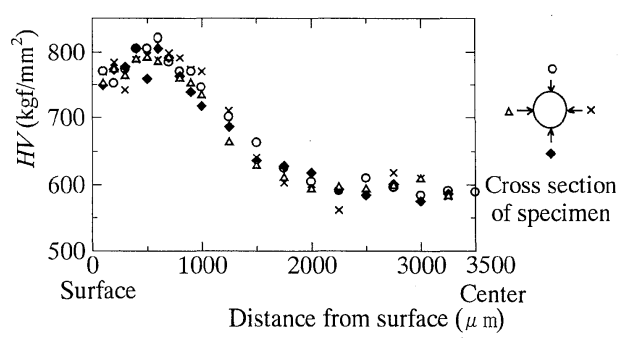

Fig. 2. Hardness Distribution across the specimen section.

していた.

試験方法は, 応力比 $R=-1$, 繰返し速度 $30 \sim 80 \mathrm{~Hz}$ の引張圧縮疲労試験で, 繰返し数 $N$ は $N=5.0 \times 10^{8}$ まで とした. 引張圧縮疲労試験では試験部に曲げがかかると 正しい值よりも低めの疲労限度が得られる。そこで試験 片の取り付けにあたっては, つかみ部付近の円周を 4 等 分する位置にひずみゲージを貼り，試験片ごとに曲げが かからないように注意深くチェックした。

\section{3 実験結果および考察}

\section{$3 \cdot 1$ 破断起点の分布とその原因}

Fig. 3 に破断起点になった介在物の寸法と位置の分布 を示す. 破断起点は, 表面からの深さ $1700 \mu \mathrm{m}$ 以上の内 部に集中している.これは, Fig. 2 に示した硬さの分布 と, 表面付近の圧縮残留応力の影響によるものである. 破断面には典型的なフィッシュ・アイが観察され，その 中心部には介在物が存在していた. 介在物は, 球形で $\mathrm{Al}$, $\mathrm{Ca}$ を含むことから考えて $\mathrm{Al}_{2} \mathrm{O}_{3} \cdot(\mathrm{CaO})_{\mathrm{x}}$ タイプの複合酸 化物であると考えられる。

このように破断起点が短寿命領域から超長寿命領域ま での全ての試験片で内部の同系統の介在物であったので 破壊起点の種類や位置の違いに関係なく，破断寿命の違 いによって破面の様子がどのように異なるかを詳しく検 討することができた.

\section{$3 \cdot 2 S-N$ 線図および修正 $S-N$ 線図}

Fig. 4 に $S-N$ 線図を示す. Fig. 4 に示すようにこのよ うな通常の $S-N$ 線図では，データのばらつきが非常に大 きい，この原因としては，Fig. 3 に示すように試験部に 含まれる最大の介在物の寸法に大きなばらつきがあるこ と, 試験部の硬さが一様ではないこと, 残留応力の影響 等が考えられる.

介在物の大きさのばらつきを評価する手法としては極

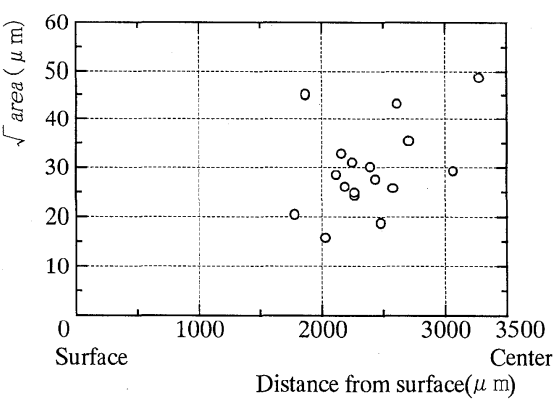

Fig. 3. Size and radial distribution of the inclusions at fracture origin.

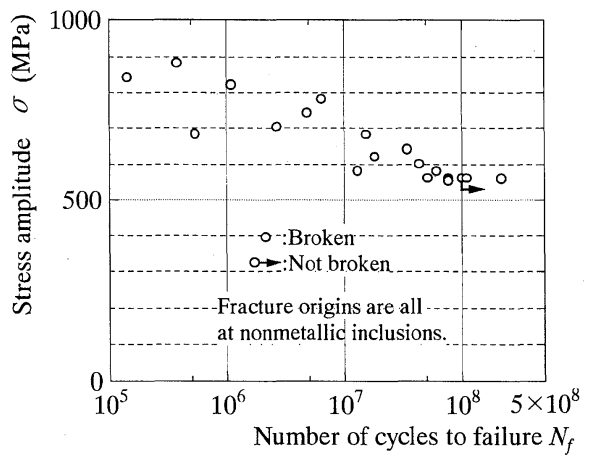

Fig. 4. $S-N$ data for SCM435.

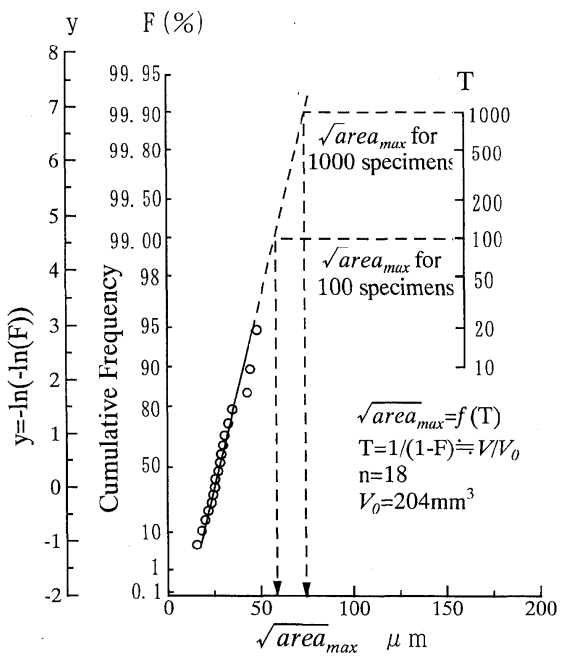

Fig. 5. Statistical distribution of inclusions at fracture origin for SCM435.

值統計法が知られている ${ }^{5)}$. Fig. 5 に試験片の破断起点 の介在物の極值統計を示す. Fig. 5 の分布の直線性は良 く，ほぼ極值分布に従っている。ここでは基準体積 $V_{0}$ と しては試験片の危険部（試験片中央の平行部の内部の軟 らかい部分）の体積をとっている. Fig. 5 の分布から極 值統計によってこの材料のもっと大きな体積中あるいは， もつと多数の試験片中に存在する最大の介在物の寸法 $\sqrt{\text { area }}_{\text {max }}$ を予測することができる。また，その予測結 果と $\sqrt{\text { area }}$ パラメータモデル ${ }^{5), 6)}$ を組み合わせることで この材料から作られた部品やロットの疲労限度の下限值 を予測することができる。

介在物の寸法の影響を評価するために $\sqrt{\text { area }}$ パラメー 
タモデルを用いて各試験片の疲労限度 $\sigma_{w}$ を推定した。

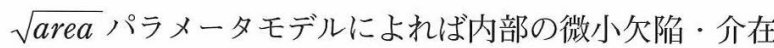
物から破壊が起こる場合の疲労限度は，次の式によって 表される.5),6)

$$
\sigma_{w}=1.56(H V+120) /(\sqrt{\text { area }})^{1 / 6}[(1-R) / 2]^{\alpha}
$$

ここで各量の定義および単位は次に示すとおりである.

$\sigma_{w}$ : 推定疲労限度, $\mathrm{MPa}$

$H V$ : ビッカース硬さ, $\mathrm{kgf} / \mathrm{mm}^{2}$

$\sqrt{\text { area }}$ : 微小欠陥・介在物の投影面積の平方根, $\mu \mathrm{m}$

$R \quad$ : 応力比, $\sigma_{\min } / \sigma_{\max }$

$\alpha=0.226+H V \times 10^{-4}$

破断起点は全て内部であったので, Fig. 2 の内部の $H V$ の最低值 $561\left(\mathrm{kgf} / \mathrm{mm}^{2}\right)$ を破断起点の $H V$ こ仮定 して式 (1) を適用した。内部の残留応力については，引 張残留応力が分布していると考学られるが，経験的に表 面から $1700 \mu \mathrm{m}$ 以上では，それほど大きくはないと考え， 考慮しなかった。したがって $R=-1$ とした。引張残留 応力を考慮すれば, 式 (1)による疲労限度の推定值は, 若干小さくなると考えられる。

Fig. 6 に各試験片の推定疲労限度 $\sigma_{w}$ に対する負荷応 力振幅 $\sigma$ の比 $\sigma / \sigma_{w}$ を縦軸にとって描いた修正 $S-N$ 線図 (1)を示す. Fig. 6のように $\sigma / \sigma_{w}=1.0$ 程度の試験片は, $N \geqq 10^{7}$ の超長寿命領域で破断している. $\sigma / \sigma_{w}=0.898$ の試験片は $N=10^{8}$ で非破断であった（図中いをつけた もの)．この試験片はこの後応力をかえて再実験したとこ ろ $\sigma / \sigma_{w}=0.994$ で $N_{f}=1.84 \times 10^{7}$ で破断した。 これか ら $\sqrt{\text { area }}$ が測定できたので $N=10^{8}$ で非破断の試験片に ついても $\sigma / \sigma_{w}$ が計算できた。また， $\sigma / \sigma_{w}=0.927$ の試 験片が $N_{f}=1.11 \times 10^{8}$ で, $\sigma / \sigma_{w}=0.835$ の試験片が $N_{f}=$ $2.17 \times 10^{8}$ で破断するなど $N \geqq 10^{8}$ の超長寿命領域でも疲 労破壊が起きている。 また，図中のプロット点は $N \geqq 10^{8}$ の超長寿命領域でも右下がりの傾向を示している。これ らの結果は, $\sqrt{\text { area }}$ パラメータモデルによる疲労限度の 推定が, $N=10^{8}$ 程度の繰返しで $10 \%$ 程度危険側になつ ており， $N \geqq 10^{8}$ の超長寿命領域でも明確な疲労限度が 現われていないことを示している.

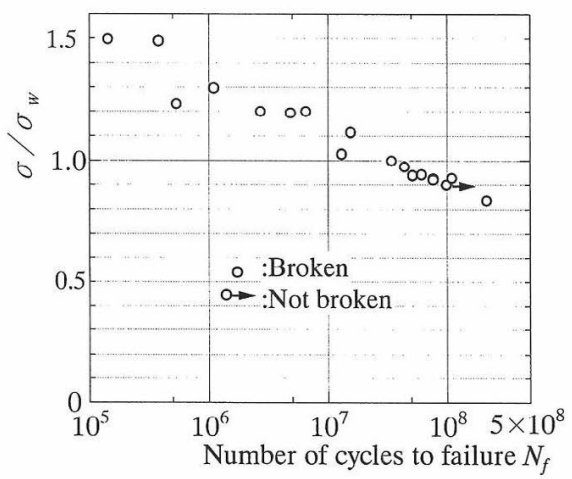

Fig. 6. A type 1 modified $S-N$ data for SCM435. $\sigma=$ Stress amplitude.

$\sigma_{w}=$ Fatigue limit calculated by the $\sqrt{\text { area }}$ parameter model.

\section{$3 \cdot 3$ 破断面の観察結果および考察}

今回の実験で破断した試験片の破断面に観察されたフ イッシュ・アイの大きさは, 1 〜 $4 \mathrm{~mm}$ 程度であった. $N_{f}$ $\geqq 10^{8}$ とすると, 平均き裂進展速度は $(0.1 \sim 0.4) \AA /$ cycle

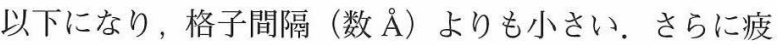
労の初期のき裂進展速度は, 平均き裂進展速度よりもは るかに小さいと考えられるから, 疲労過程の初期には, き裂が 1 サイクルごとに進展したとは考え難いことにな る.すなわち, 超長寿命疲労の初期段階では, き裂はあ る繰返し数ごとに不連続に進展したものと考えねばなら ない.

そこで破断起点となった介在物の周辺を注意深く観察 すると，短寿命で破断したものと長寿命で破断したもの とでは, 介在物近傍の様子が大きく異なっていることが わかった. Fig. 7 に破断起点となった介在物およびその 近傍の金属顕微鏡写真を示す. Fig. 7 (a) 〜 (d) の 4 枚 の写真を比較すると, (b), (c), (d) では, 介在物の周辺 に黒く見える部分が存在するのに対して(a) にはそのよう な部分は見当たらない，この違いは，(a) が $N_{f}=5.40 \times$ $10^{5}$ と短寿命，(b)，(c)，(d) が， $N_{f} \geqq 10^{7}$ と長寿命であ ったことによるものと考えられる。今回の実験結果では, $N_{f}=10^{6}$ 程度を境界として黒くみえる部分が存在するも のと存在しないものとに分れていた。

Fig. 8 は黒くみえる部分と寿命の長短の関係を調べた ものである．Fig. 8 は［介在物の寸法］に対する [介在 物 +黒くみえる部分］の寸法の比と破断繰返し数の関係 を示している。介在物の寸法に対して相対的に大きな黒 くみえる部分を持つ試験片ほど，長い寿命を有している 傾向があることがわかる。このことから黒くみえる部分

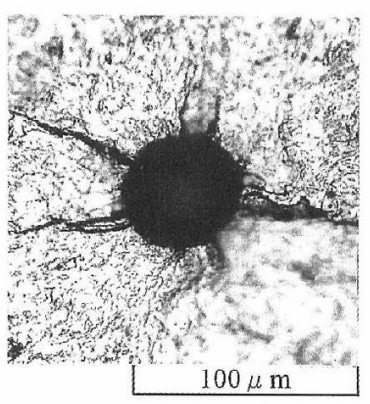

(a) $\sigma=682(\mathrm{MPa})$ $N_{f}=5.40 \times 10^{5}$

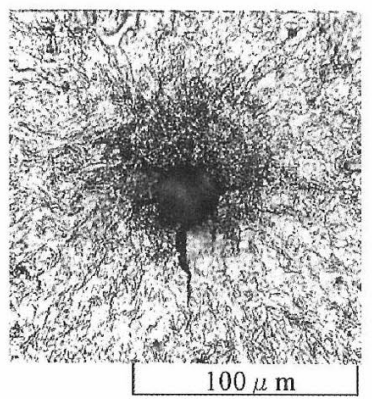
$N_{f}=4.39 \times 10^{7}$ (c) $o=601(\mathrm{MPa})$

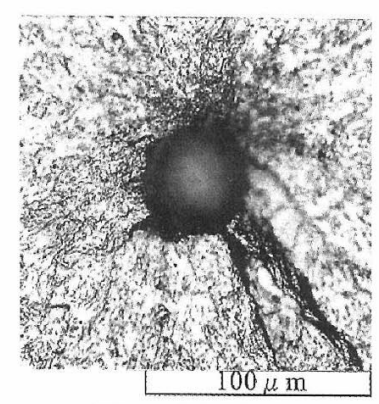

(b) $\sigma=581(\mathrm{MPa})$ $N_{f}=1.31 \times 10^{7}$

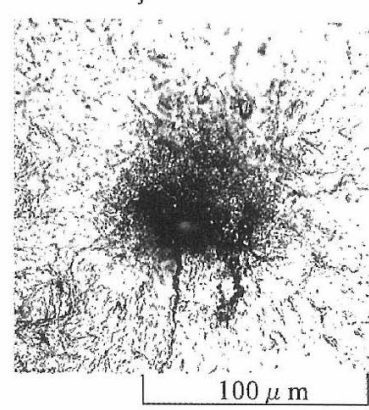

(d) $\sigma=560(\mathrm{MPa})$ $N_{f}=2.17 \times 10^{3}$
Fig. 7. Dark area beside the inclusion at fracture origin (SCM435). 


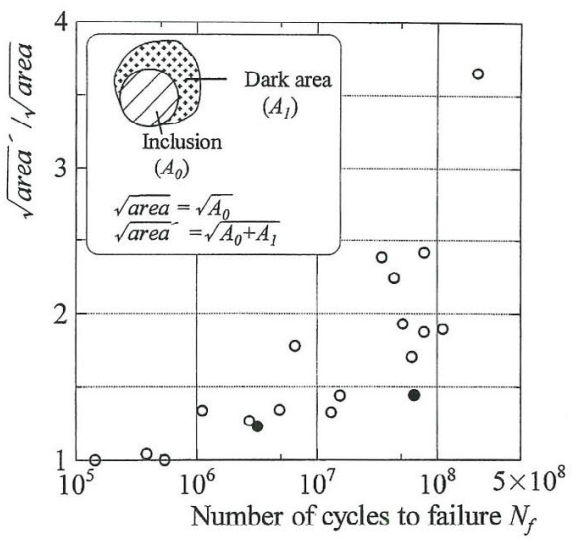

Fig. 8. Relationship between the size of the dark area and cycles to failure.

$\sqrt{\text { area }}=$ Inclusion size

$\sqrt{\text { area }}^{\prime}=$ Inclusion size + the size of the dark area.

- : Specimens annealed at $300^{\circ} \mathrm{C}$.

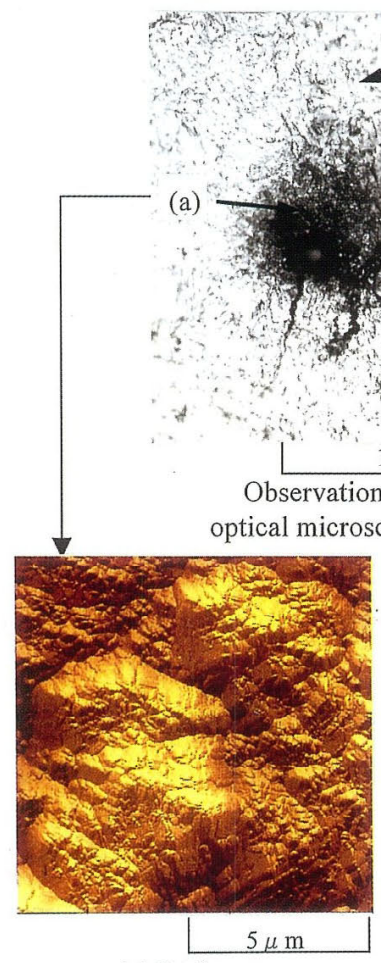

(a) Dark area (b)

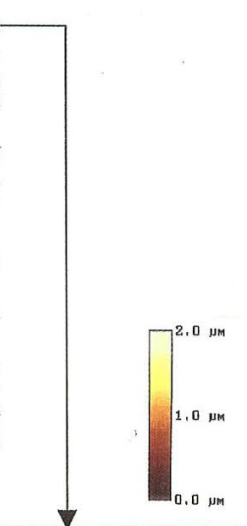

Fig. 9. AFM observation of fracture surface (SCM435). $\sigma=560(\mathrm{MPa}), N_{f}=2.17 \times 10^{8}$

はき裂がきわめてゆっくりと進展して形成された部分と 考えられる。したがって，この黒い部分の形成が $N \geqq 10^{7}$ での疲労破壊に大きく関わっていると考えられる.

Fig. 9 (a) に金属顕微鏡観察で黒くみえる部分の AFM 写真を示す. Fig. 9 (b) はその外側の顕微鏡写真で白く みえる部分の AFM 写真である. Fig. 9 (b) では平坦で高 低差の小さいしわ状の破面が観察されているのに対して， Fig. 9 (a) では回凸が大きく粗い破面となっている.

Fig. 10 は破断起点となった介在物, 黒い部分扎よび その外側の白い部分の SEM 写真である。白い部分では, 典型的なマルテンサイト組織の疲労破面が観察されてい

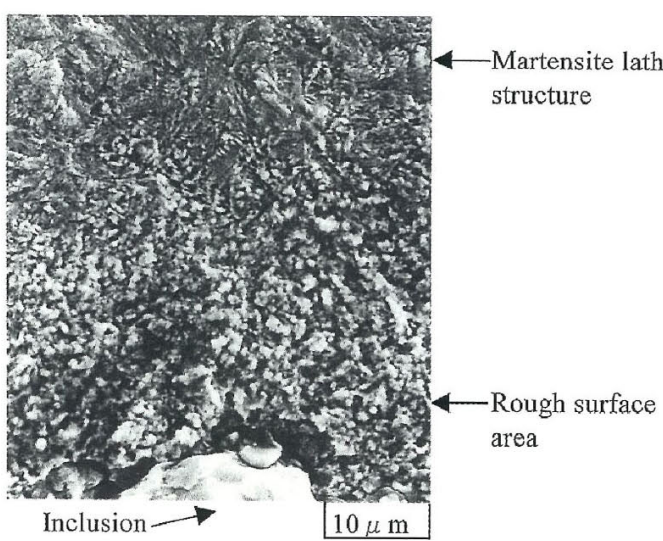

Fig. 10. SEM observation of fracture surface (SCM435). $\sigma=560(\mathrm{MPa}), N_{f}=2.17 \times 10^{8}$

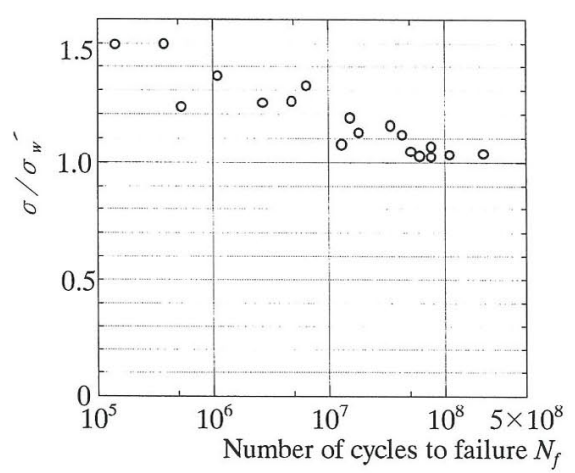

Fig. 11. A type 2 modified $S-N$ data for SCM 435 .

$\sigma=$ Stress amplitude.

$\sigma_{w}{ }^{\prime}=$ Fatigue limit calculated by the $\sqrt{\text { area }}$ parameter model taking the dark area into consideration.

るが，黒い部分では，通常の疲労破面と比較して一見ぜ い性的な粗い破面となっている。このことから黒い部分 とその外側の白い部分では, 明らかに破壊機構が異なっ ていると考えられる。黑い部分は通常の痏労機構とは異 なる疲労機構によってき裂が進展してできたものである と考えられる。すなわち，このような異なる破面は，ま ず特殊な痩労機構によってき裂がある限界寸法まで進展 した後, 通常の疲労機構によるき裂の進展が開始されて 形成されると考えられる。

そこで元の介在物と黒い部分をあわせた部分の寸法 $\sqrt{\text { area' }}$ (Fig. 8) を有効な欠陷寸法とみなして $\sqrt{\text { area }}$ パ ラメータモデルを適用し, 黒い部分も欠陥であるとみな した場合の推定疲労限度 $\sigma_{w}{ }^{\prime}$ を計算した. Fig. 11 にこ の新しい推定疲労限度 $\sigma_{w}{ }^{\prime}$ に対する負荷応力振幅 $\sigma$ の比 $\sigma / \sigma_{w}{ }^{\prime}$ を縦軸にとった修正 $S-N$ 線図(2)を示す. Fig. 11 のプロット点が全て $\sigma / \sigma_{w}{ }^{\prime} \geqq 1$ になっていることから，上 述の仮説が妥当なものと考えることができる.

このような超長寿命疲労に打ける黒い部分の形成が, SCM435に特有のものなのかそうではないのかを検討す るために，著者ら ${ }^{7)}$ が以前に疲労試験を行った S45C 焼 入れ焼もどし材の引張圧縮痒労試験片の破断面を観察し た. Fig. 12 に $45 \mathrm{C}$ の破断起点とその周辺の金属顕微鏡 写真を示す. Fig. 12 から S45C の場合にも SCM435の 


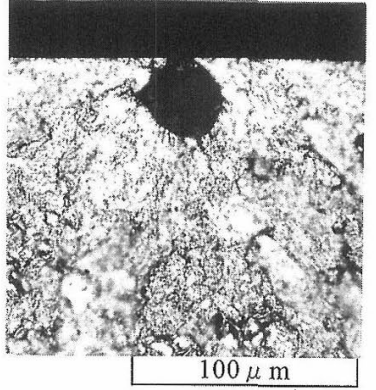

(a) $\sigma=676.2(\mathrm{MPa})$ $N_{f}=5.94 \times 10^{4}$

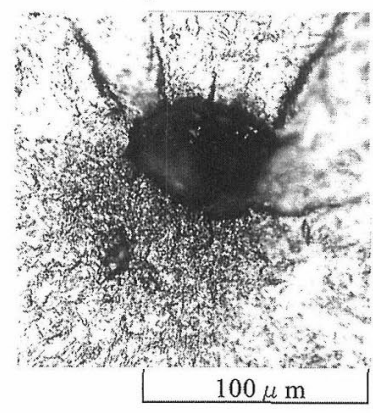

(c) $\sigma=529.2(\mathrm{MPa})$ $N_{f}=8.96 \times 10^{7}$

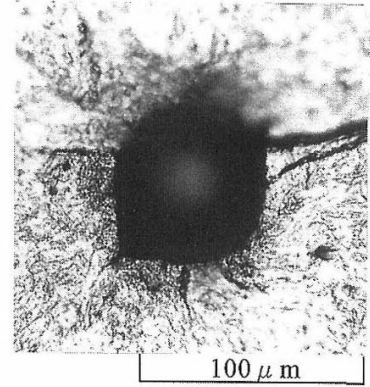

(b) $\sigma=588(\mathrm{MPa})$ $N_{f}=3.11 \times 10^{7}$

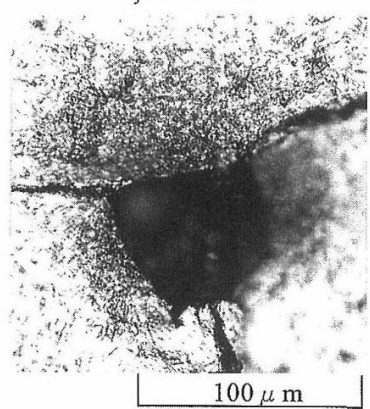

(d) $\sigma=509.6(\mathrm{MPa})$ $N_{f}=9.70 \times 10^{7}$
Fig. 12. Dark area beside the inclusion at fracture origin $(\mathrm{S} 45 \mathrm{C})$.

場合と同粎に長寿命で破断した試験片の破断起点の介在 物周辺には黑くみえる部分が存在し，短寿命で破断した 試験片の破断起点の周辺にはそのような部分は見当たら ないことがわかる。したがって超長寿命疲労に伴なう黒 くみ气る部分の形成は，SCM435 に限らず高強度鋼に共 通の現象であることが予想される。

\section{$3 \cdot 4$ 金属顕微鏡で黒く見える部分の疲労機構}

以上のように高強度鋼の超長寿命領域に打ける疲労破 溒には金属顕微鏡で黒く見える部分の形成が深く関わっ ていると考元られるが，この部分がぜい性的な破面と考 えられることと不連続に非常にめっくりとき裂が進展し た部分であると考光られることから，本研究では黒くみ える部分は，水素ぜい化等による遅れ破壊に類似の現象 ${ }^{8)}$ が関与して形成されたのではないかと考えた， $\mathrm{H}_{2}$ を直接 检出したわけではないが，水素ぜい化の可能性を示唆す るいくつかの傍証はある。例えば金属材料中の非金属介 在物の周辺には，水素がトラップされていることが知ら れている.9) また熱処理を施した高強度鋼には残留応力が 存在するが，青木ら ${ }^{10)}$ は水素チャージした高強度ばね鋼 が引張残留応力下で遅れ破壞を起こすことを報告してい る。非金属介在物の熱膨張係数は，母材の鋼とは異なる ので介在物周辺には局所的に引張残留応力が作用する。 このように非金属介在物の周辺には, 初期から水素がト ラップされている条件が直ることに加えて $N \geqq 10^{8}$ のよ うな長寿命の疲労試験を行えば，大気中でも試験片中の 非金属介在物の周辺に水素が集積する可能性は十分に ある。

著者ら ${ }^{11)}$ が以前に疲労試験したエレクトロンビーム溶 解した超清浄軸受鋼では，含まれている介在物が非常に

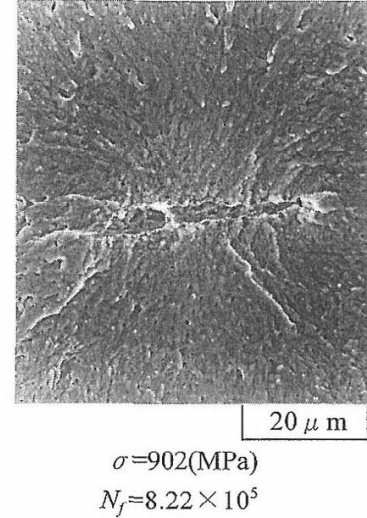

(a)The fracture surface of the specimen broken from a bainite.

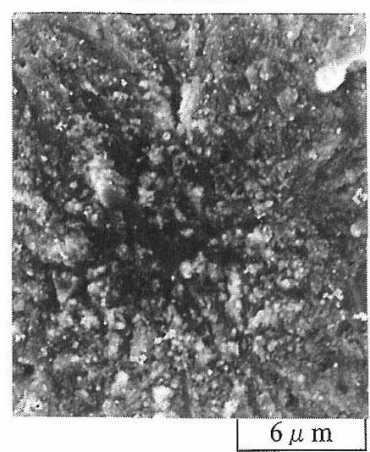

$\sigma=1099(\mathrm{MPa})$

$N_{f}=4.04 \times 10^{6}$

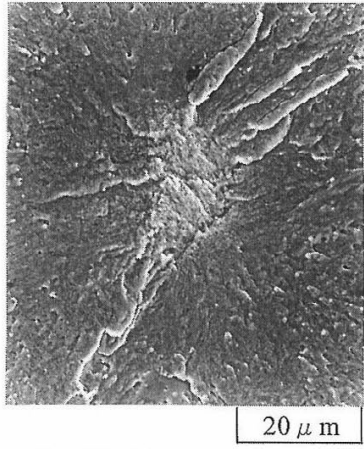

$\sigma=1074(\mathrm{MPa}) \Rightarrow \sigma=1145(\mathrm{MPa})$

$N_{f}=5.0 \times 10^{7} \Rightarrow N_{f}=1.30 \times 10^{7}$

(b)The fracture surface of the specimen

broken from a bainite

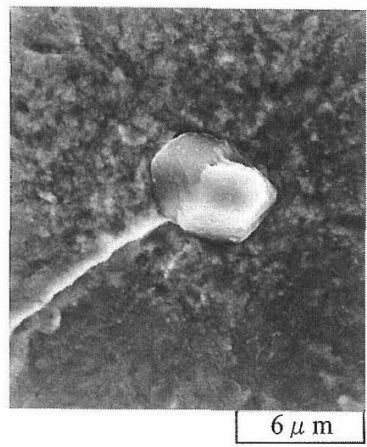

$\sigma=1053(\mathrm{MPa})$

$N_{f}=2.03 \times 10^{7}$

(c) The fracture surface of the specimen (d)The fracture surface of the specimen broken from an inclusion( $\mathrm{MnS})$.

broken from an inclusion $\left(\mathrm{Al}_{2} \mathrm{O}_{3}\right)$

Fig. 13. Fracture surface of the electron beam remelted super clean bearing steel.

小さいためにほとんどの試験片が介在物ではなく基地組 織のマルテンサイト $(H V 〜 770)$ よりも軟らかいべイナ イト $(H V \sim 560)$ から破墑した. Fig. 13 にエレクトロン ビーム溶解した超清浄軸受鋼の破面のSEM 写真を示す。 ベイナイトを起点として破断した試験片（Fig. 13 (a)， (b)）のベイナイト周辺には，粗い部分（金属顕微鏡で黑 く見える部分）がないことがわかる，一方，少数ではあ るがこの超清浄軸受鋼でも介在物が疲労破壞起点となっ た例 (Fig. 13 (c)，(d))があった。 それらの場合は介在物 周辺に粗い破面が生じているのがわかる。このことは， 黒くみえる部分が介在物起点による破壊に特有の形態で 南る可能性を示唆している。また，ベイナイトには介在 物ほざ水素を集積させる性質がないので, Fig. 13 は黒 くみえる部分の形成に水素が関与していることの間接的 な証拠である。

以上のことから黒くみえる部分は, 介在物周辺に集積 した水素の影響と繰返し応力との連成による遅れ破壊に 類似の機構でき裂が進展した結果生じたものと考えら れる.

\section{$3 \cdot 5$ 水素の関与に関する検証}

Fig. 14 に超長寿命領域における疲労破壞の模式図を 示す. 図に示したように介在物近傍に集積した水素の影 響と繰返し応力の相互作用によって黒くみえる部分（表 面の粗い部分）が形成されるとすれば，介在物周辺の水 
素の量を減らすことで黒くみえる部分の形成を抑制でき ると考えられる。高井ら ${ }^{12), 13)}$ は， $570 \mathrm{~K}$ 程度の温度に 加熱すれば，Ca 系介在物にトラップされた水素が放出さ れることを報告している。 Fig. 15 に高井らが介在物周 辺から放出される水素を 2 次イオン像分析によって可視 化して撮影した写真を示す．眓中の矢印で示した部分が 析出物あるいは介在物から水素が放出されている部分で あるそこで本研究で用いた SCM435 の試験片 2 本に $300^{\circ} \mathrm{C}(573 \mathrm{~K}), 1 \mathrm{~h}$ の真空焼なましを施した後疲労試験 を行い，破断起点を観察した。

Fig. 8 ので示したデータがこの真空焼なましした試 験片の結果である。この 2 本の試験片は, 同程度の繰返 し数で破断した他の試験片に比べて介在物の大きさに対 する黒くみえる部分の大きさが小さい傾向にあることが 分かる．このことは，真空焼なましによって水素が放出 されたために黒くみえる部分の形成が抑制されたことを 示唆している。このように黒くみえる部分の形成には水 素が重要な役割を担っているものと考えられる。

\section{4 結言}

これまで超長寿命域での疲労破壊は真空中であること に起因する疲労現象との観点による説明が多くなされて

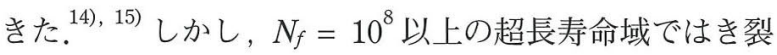
が 1 サイクルごとに進展するとは考えられないことを考

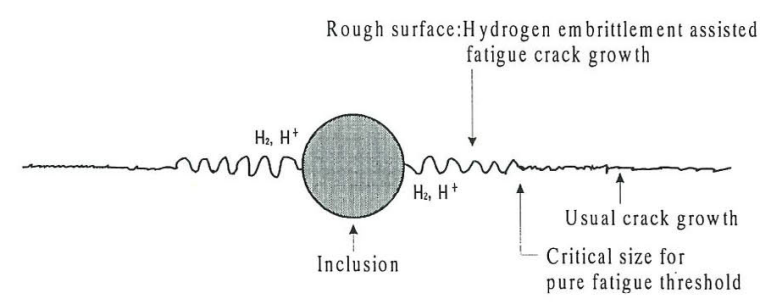

Fig. 14. A mechanism schematic for superlong fatigue failure associated with hydrogen embrittlement coupled with a cyclic stress.

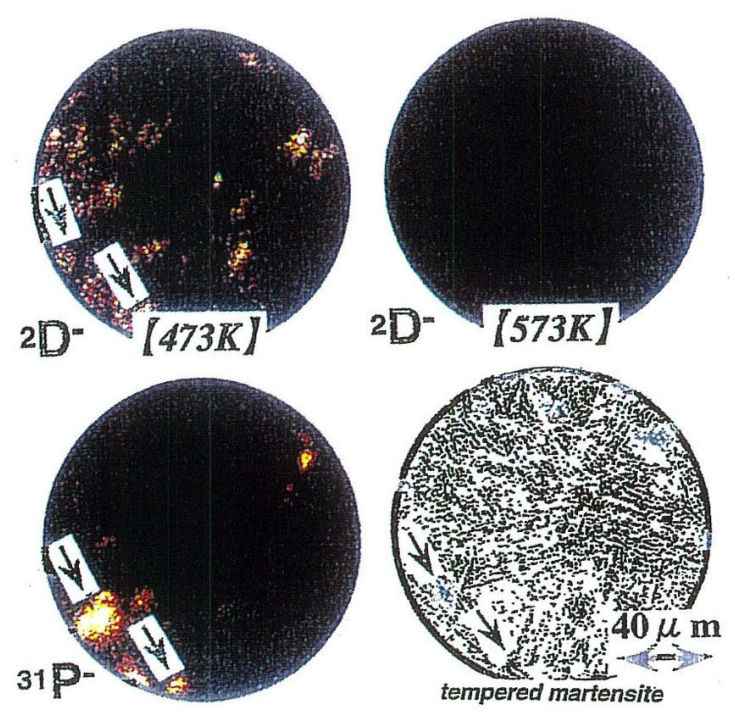

Fig. 15. Secondary ion images of ${ }^{2} \mathrm{D}^{-}$, and ${ }^{31} \mathrm{P}^{-}$after heating at $473 \mathrm{~K}$ and $573 \mathrm{~K}$ by TDS, and optical microstructure of PC bar (K. Takai ${ }^{12)}$ ).
慮すると，真空中の疲労ということでは説明できない， また，多くの場合 $S-N$ 線図に一旦水平部が現われること は, 疲労限度を示すき裂進展の threshold 現象は現われ ていると見るべきである，本研究では，環境因子を考虑 しなければこのような超長寿命領域における疲労破壊現 象の説明は困難と考え, 介在物にトラップされた水素の 影響に注目し，この観点を支持するいくつかの証拠を示 した. 以下に具体的結論を述べる.

（1）低応力で超長寿命疲労破壊した試験片の破断起 点の介在物周辺には, 金属顕微鏡で黒くみえる粗い部分 が観察された。短寿命で破断した場合には，このような 黒い部分は観察されず, 破断繰返し数が大きい試験片ほ ど介在物の寸法に対して相対的に大きな黒い部分が観察 された。

(2) この黒い部分はその外側の典型的なマルテンサイ 卜組織の疲労破面とは全く異なる粗い破面になっており, 通常の疲労とは異なる機構で不連続に非常にゆっくりと き裂が進展したものと考えられる。

（3）非金属介在物の周辺には水素が集積しやすいこと や，黒い部分のき裂の進展が非常に遅く不連続であるこ とから，黒い部分の破壊機構は，水素ぜい化と繰返し応 力の連成によって引き起こされた遅れ破壊に類似の機構 であると考えられる。

\section{参 考 文 献}

1）江村秀樹，浅見克敏，日本機械学会論文集，A-55，45 (1989)

2) 黒島義人, 清水真佐男, 川峷一博, 日本機械学会論文集, A-59, 1001 (1993).

3) 阿部孝行, 金澤健二, 材料, 45, 9 (1996).

4 ）中村 孝, 金子 真, 野山 徹, 神保勝久, 日本機械学 会論文集，A-64，1820（1998）。

5）村上敬宜, “金属疲労：微小久陥と介在物の影響”（1993） 養賢堂.

6) Y. Murakami and M. Endo, “EGF Pub. 1”, Eds. K. J. Miller and E. R. de los Rios, p.275 (1986) Mech. Engng. Pub..

7) 村上敬宜, 高田昌幸, 鳥山寿之, 材料, 46, 1149 (1997).

8 ）松山晋作，“遅れ破壞”（1989）日刊工業新聞社.

9 ）下田秀夫, “鉄鋼製品破損事故の調查·解析法と原因の究 明”(1996) 産業化学システムズ.

10）青木利憲, 脇田将見，小兽根敏夫，ばね論文集， 43,42 (1998).

11）鳥山寿之, 村上敬宜, 山下晃生, 坪田一一, 古村恭三郎, 鉄と鋼, 81 (1995).

12）高井健一, 本間芳和, 井筒香, 南雲道彦, 日本金属学会 誌, 60, 1155 (1996).

13）高井健一, (社) 日本鉄鋼協会材料の組織と特性部会高強度鋼 の遅れ破壊研究会, 41, “遅れ破猿解明の新展開”(1997).

14）金澤健二, 西島 敏, 材料, 46, 1396 (1997).

15）黒島義人, 池田 隆, 原田三徳, 原田昭治, 日本機械学 会論文集，A-64，2536（1998）。 